\title{
Band Gap Enhancement and Temperature Dependent PL in Sol-gel Synthesized Ce Doped ZnO Nanoparticles
}

\author{
Ashok Kumawat, Saikat Chattopadhyay, Nilanjan Halder, Kamakhya Prakash Misra* \\ Department of Physics, School of Basic Sciences, Manipal University Jaipur, 303007 Rajasthan, India
}

(Received 10 January 2021; revised manuscript received 25 March 2021; published online 09 April 2021)

\begin{abstract}
Sol-gel synthesis route was adopted to prepare undoped and 2 at. \% Ce doped $\mathrm{ZnO}$ (CZO) nanoparticles (NPs). Distinct characteristic absorption peaks at 520 and $524 \mathrm{~cm}^{-1}$ are seen in FTIR spectra of NPs, which generally correspond to $\mathrm{Zn}-\mathrm{O}$ stretching mode. This confirmed the formation of $\mathrm{ZnO}$ in the samples. Other peaks at 628 and $631 \mathrm{~cm}^{-1}$ were also observed corresponding to $\mathrm{Zn}-\mathrm{O}-\mathrm{Zn}$ antisymmetric vibrations UV-Vis transmission spectra revealed absorption dips at 370 and $364 \mathrm{~nm}$ respectively for undoped ZnO and CZO NPs and the corresponding band gap values were estimated to be 3.34 and $3.41 \mathrm{eV}$. The photoluminescence (PL) emission spectra of undoped ZnO NPs had one major peak at $391 \mathrm{~nm}$ (UV) along with feeble visible peaks at 467, 480 and $492 \mathrm{~nm}$. The UV peak observes a continuous rise in intensity with reduction in temperature ranging from $50{ }^{\circ} \mathrm{C}$ to $-10^{\circ} \mathrm{C}$. The UV peak also blue-shifted slightly with temperature lowering. The temperature dependent PL spectra of CZO NPs too had similar peaks but a very feeble change in the intensity with temperature was noticed and the blue-shift of the UV peak occurred at negative temperature. The temperature dependent PL properties and band gap enhancement in CZO NPs may have potential applications in optoelectronics.
\end{abstract}

Keywords: Sol-gel method, CeZnO, Band gap enhancement, Temperature dependent PL, Optoelectronics applications.

DOI: $10.21272 /$ jnep.13(2).02001

PACS numbers: 78.55.Kz, 42.70.Qs

\section{INTRODUCTION}

$\mathrm{ZnO}$ is an $n$-type semiconducting material having a direct band gap of $3.37 \mathrm{eV}$ and an exciton binding energy of nearly $60 \mathrm{MeV}$. It presents diverse morphological structures such as nanorods, core shells, nanowires, helix, nanobelts, nanoplatelets and nanotubes which show many potential applications. $\mathrm{ZnO}$ is also a good host for doping transition, rare earth and post-transition metals. Several dopants have been tried to impact its optical, electrical, magnetic and morphological properties [1-7]. Family of rare earth ions can make various well defined narrow optical transitions between the spin-orbit levels split under the different manifold's weak crystal field. Shielding effects of the $5 \mathrm{~s}$ and $5 \mathrm{p}$ orbitals allow the photoluminescence (PL) spectra of rare-earth ions to show emission frequencies, which are relatively host independent. The variation in optical band gap attributed towards the presence of oxygen defects and formation of new states due to doping level of $\mathrm{Yb}$ [5]. The absorption spectrum and the reflectivity of $\mathrm{Tb}$-doped $\mathrm{ZnO}$ decrease with increasing $\mathrm{Tb}$ concentration [6]. The use of rare earth as dopants (such as $\mathrm{Ce}, \mathrm{Tb}, \mathrm{La}, \mathrm{Nd}$ and $\mathrm{Eu}$ ) has raised great interest as a route to enhance the electrical and luminescent properties of $\mathrm{ZnO}$. Rare earth element doped $\mathrm{ZnO}$ nanoparticles are therefore one of the most promising materials for the fabrication of optoelectronic devices.

Out of several rare earth elements, Ce has attracted significant attention because of its proved capacity to trap the photoinduced charge carriers due to its unique 4f-electronic configuration and the defects introduced in the $\mathrm{ZnO}$ matrix because of the doping process. The optical properties for undoped and Ce doped $\mathrm{ZnO}$ show the reduction of the band gap energy from $3.4 \mathrm{eV}$ down to $2.81 \mathrm{eV}$ for heavy doping of $\mathrm{Ce}$ [7]. Introduction of Cerium in $\mathrm{ZnO}$ reduces the emission intensity lines by energy transfer from the $\mathrm{ZnO}$ to Cerium [8].

There are various methods of synthesis of $\mathrm{ZnO}$ NPs. Some of them require complex processes and sophisticated equipment such as chemical vapor deposition, magnetron sputtering and laser ablation etc. In contrast, there are some chemical and simple approaches such as wet chemical processes, thermal decomposition, sol-gel process, co-precipitation method and hydrothermal synthesis route etc.

The sol-gel technique allows mixing of the chemicals at atomic level, thus reducing the possibility of undetectable impurity phases. Therefore, in the present study, Ce doped ZnO NPs have been synthesized by solgel method and their optical and morphological properties are presented here.

\section{RESULTS AND DISCUSSION}

\subsection{Synthesis}

To prepare the undoped $\mathrm{ZnO} \mathrm{NPs}$, we used the $0.2 \mathrm{M}$ solution of zinc acetate dihydrate $\left(\mathrm{Zn} .\left(\mathrm{CH}_{3} \mathrm{COO}\right)_{2} \cdot 2 \mathrm{H}_{2} \mathrm{O}\right)$ (99.5\% pure, SD Fine chemicals), which was mixed with isopropyl alcohol (99.8 \% pure, Merck). Rigourous magnetic stirring was performed at $50{ }^{\circ} \mathrm{C}$ for $30 \mathrm{~min}$ to get clear homogeneous solution. An appropriate amount of $0.2 \mathrm{M}$ aqueous solution of $\mathrm{NaOH}$ were mixed dropwise until precipitation. The precipitate was filtered and subsequently rinsed with deionized water and ethanol.

For 2 at. \% doping of Cerium into $\mathrm{ZnO}, 0.2 \mathrm{M}$ solution of Cerious chloride hexahydrate $\left(\mathrm{CeCl}_{2} \cdot 6 \mathrm{H}_{2} \mathrm{O}\right)$ (97\% pure, Merck) in isopropyl alcohol was added into

* misra.kamakhya@gmail.com

The results were presented at the International Conference on Multifunctional Nanomaterials (ICMN2020) 
the precursor of undoped $\mathrm{ZnO}$, while magnetic stirring. Thereafter, $0.2 \mathrm{M}$ aqueous solution of $\mathrm{NaOH}$ was added dropwise till precipitation. This precipitate was also filtered and rinsed with deionized water and ethanol.

Finally obtained both the precipitates were kept for drying at $80{ }^{\circ} \mathrm{C}$ for $24 \mathrm{~h}$. The dried precipitates were ground to convert them into fine powder. The powder samples were kept in a muffle furnace at $300{ }^{\circ} \mathrm{C}$ for $3 \mathrm{~h}$ in air atmosphere. Undoped and 2 at. \% Ce doped $\mathrm{ZnO}$ will be referred to $S_{1}$ and $S_{2}$ respectively.

\subsection{Characterization}

To investigate the chemical composition of pure and Ce-doped $\mathrm{ZnO}$ nanostructures, Fourier Transform Infrared Spectroscopy (FTIR) (Bruker Alpha, USA) is performed in the range $500-2000 \mathrm{~cm}^{-1}$. For the investigation of energy band gap and transmission spectrum UV-Visible spectrophotometer (Shimadzu UV2600, Japan) is used within the range of $300-500 \mathrm{~nm}$ wavelength. To analysis the room temperature and temperature dependent Photoluminescence (PL) spectrometer (Horiba Fluoromax 4c, Horiba, USA) is used for analysis of undoped $\left(S_{1}\right)$ and Ce doped $\mathrm{ZnO}\left(S_{2}\right)$ samples at excitation wavelength of $325 \mathrm{~nm}$. To analysis the structural properties, particle size and distribution of the particles Field Emission Scanning Electron Microscope (FESEM) (JEOL-7610FPlus, JEOL, Japan) is used.

\section{RESULTS AND DISCUSSION}

\subsection{FTIR Spectrum}

The FTIR spectra for undoped $\left(\mathrm{S}_{1}\right)$ and $\mathrm{CZO}\left(\mathrm{S}_{2}\right)$ NPs are shown in Fig. 1. The spectra revealed the distinct characteristic absorption dip corresponding to $\mathrm{Zn}$ O stretching mode at 520 and $524 \mathrm{~cm}^{-1}$ for $S_{1}$ and $S_{2}$ respectively. This absorption in FTIR spectra of ZNO occurs due to stretching of $\mathrm{Zn}-\mathrm{O}$ coordination in tetrahedral mode. The presence such peaks confirms the formation of $\mathrm{ZnO}$ phase in NPs [9]. Another confirmation is also noticed that is the existence of $\mathrm{Zn}-\mathrm{O}-\mathrm{Zn}$ antisymmetric vibrations at 628 to $631 \mathrm{~cm}^{-1}$ respectively for $S_{1}$ and $S_{2}$. It is evident that Ce doping causes the shift of both of the $\mathrm{Zn}$ related bonds towards higher wavenumber, in FTIR spectra. Other absorption bands are observed around 954, 1071, 1251, 1397,1531 and $1696 \mathrm{~cm}^{-1}$ which correspond to $\mathrm{C}-\mathrm{H}$ out of plane bending, $\mathrm{C}=\mathrm{C}$ stretching, $\mathrm{C}-\mathrm{O}$ stretching, $\mathrm{COO}^{-}$group with $\mathrm{Zn}$ ion, $\mathrm{C}=\mathrm{C}$ stretching and $\mathrm{C}=\mathrm{O}$ bond respectively.

\subsection{Optical Properties}

UV-Visible absorption spectra were recorded to understand the influence of $\mathrm{Ce}$ addition on the optical properties of $\mathrm{ZnO}$. Fig. 2 shows the UV-Visible absorption spectra of $S_{1}$ and $S_{2}$. Absorption peaks occur at 370 $\mathrm{nm}$ and $364 \mathrm{~nm}$ for $S_{1}$ and $S_{2}$ respectively. It indicates that Ce doping causes the blue-shift of the absorption dip, whose most probable reason can the shift of the band of $\mathrm{ZnO}$ NPs due to Ce doping. To analyze the band gap, Tauc's plot is performed for which the absorption coefficient a for direct band gap materials is related to optical band gap energy according to the expression [10].

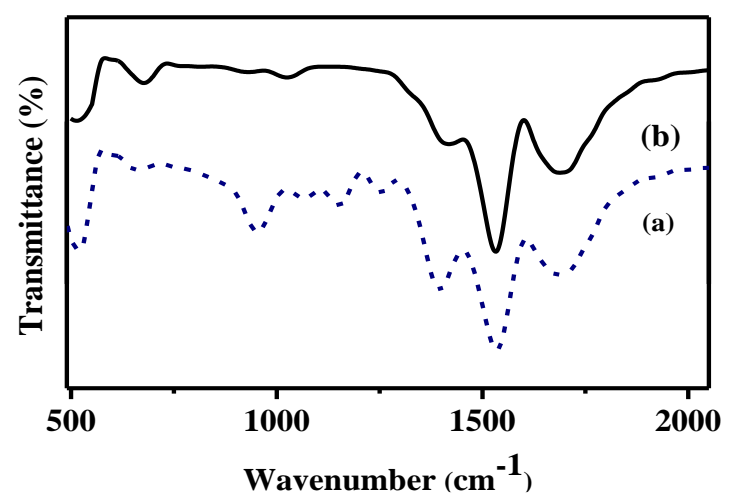

Fig. 1 - (a) and (b) FTIR spectrum of undoped and 2 at. \% Ce doped ZnO NPs

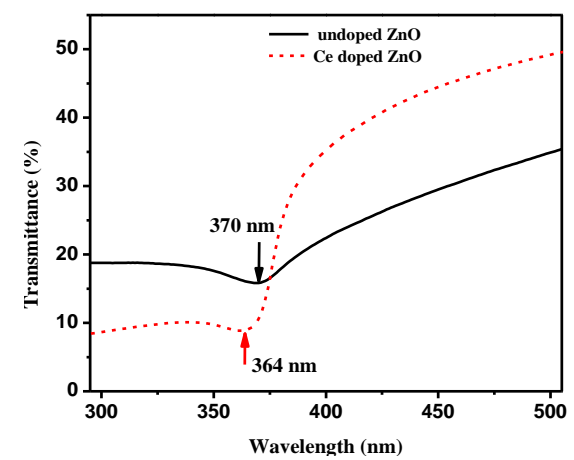

Fig. 2-UV-Visible transmittance spectra of undoped and 2 at. \% Ce-doped $\mathrm{ZnO} \mathrm{NPs}$

$$
\alpha h v=\left(h v-E_{g}\right)^{1 / 2} .
$$

Here, $h$ is Planck's constant and $v$ is the frequency of incident photon. Intercept on the photon energy axis obtained by extrapolating the linear portion of the $(\alpha h v)^{2}$ versus $h v$ curve, which gives the band gap. From the Tauc's plot as shown in Fig. 3, the values of energy band gap $\left(E_{g}\right)$ are estimated to be 3.34 and $3.41 \mathrm{eV}$ corresponding to $S_{1}$ and $S_{2}$. The band gap values obtained from the Tauc's plot are in close agreement to the energies corresponding to the absorption dips. This blueshift of the band gap can be ascribed to Burstien-Moss effect. It is reported that the optical band gap widening and narrowing happens due to the electron-electron and electron-impurity scattering respectively which is called as Burstein-Moss effect [11].

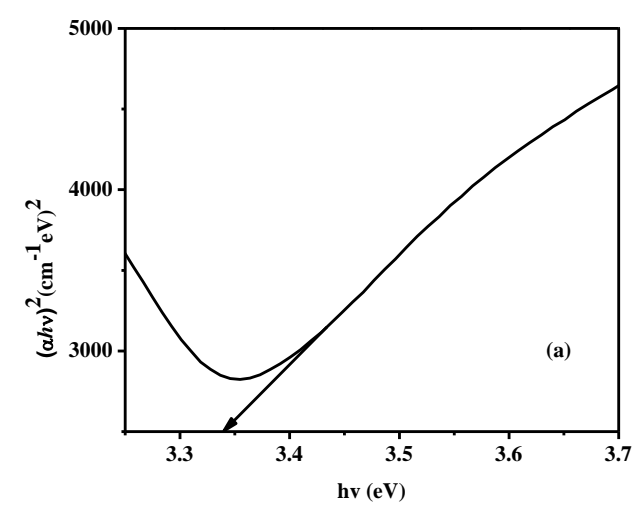




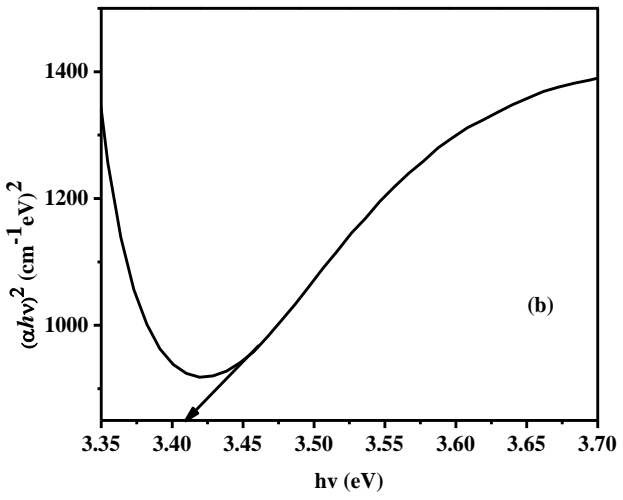

Fig. 3 - (a) and (b) shows Tauc's plot for undoped and 2 at. \% Ce doped $\mathrm{ZnO}$ respectively

\subsection{Morphological Properties}

Fig. 4 and Fig. 5 show the FESEM images of undoped $\mathrm{ZnO}$ and CZO NPs at the scale of $100 \mathrm{~nm}$ with the appropriate magnification. The image (b) in both the case is at higher magnification. More of a platelet structures are visible in undoped $\mathrm{ZnO}$ whose average size is found to be nearly $22 \mathrm{~nm}$. The shape and size both change due to Ce doping $\mathrm{ZnO}$. Prominently hexagonal rod-like structures are seen in Fig. 6. The average size of these structures nearly $67 \mathrm{~nm}$.
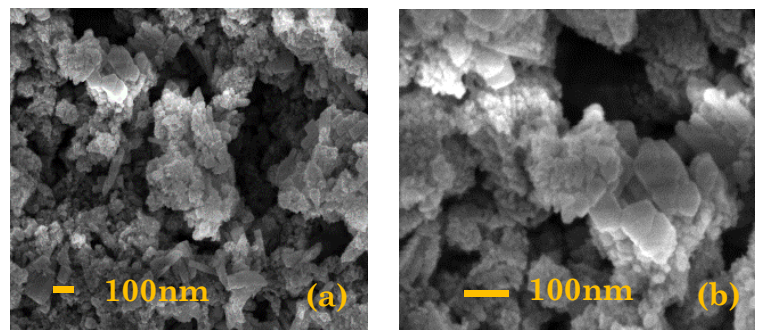

Fig. 4 - (a) and (b) FESM image of undoped ZnO NPs at different magnification
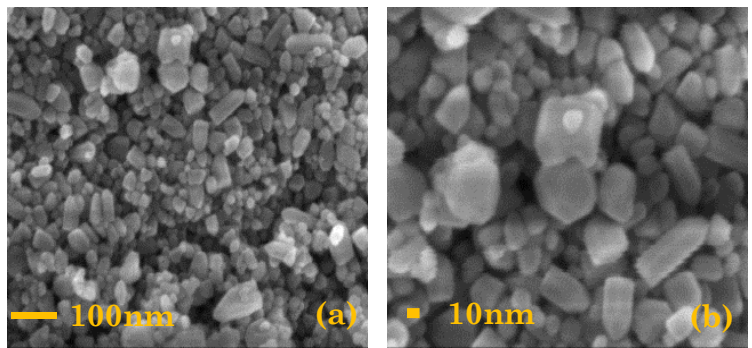

Fig. 5 - (a) and (b) FESM image of undoped ZnO NPs at different magnification

\subsection{PL Studies}

Fig. 6 displays the temperature dependent PL emission spectra of the undoped $\mathrm{ZnO}$ and $\mathrm{CZO}$ NPs recorded at excitation wavelength of $325 \mathrm{~nm}$. The PL emission spectra of undoped $\mathrm{ZnO}$ NPs contains one major peak at 391 along with three other feeble peaks at 467, 480 and $492 \mathrm{~nm}$. The first peak originates from due the recombination of free electrons from valence band to conduction band. The UV emission (391 nm) observes a blue-shift of the peak and a continuous rise in its intensity with reduction in temperature from $50{ }^{\circ} \mathrm{C}$ to $-10{ }^{\circ} \mathrm{C}$.
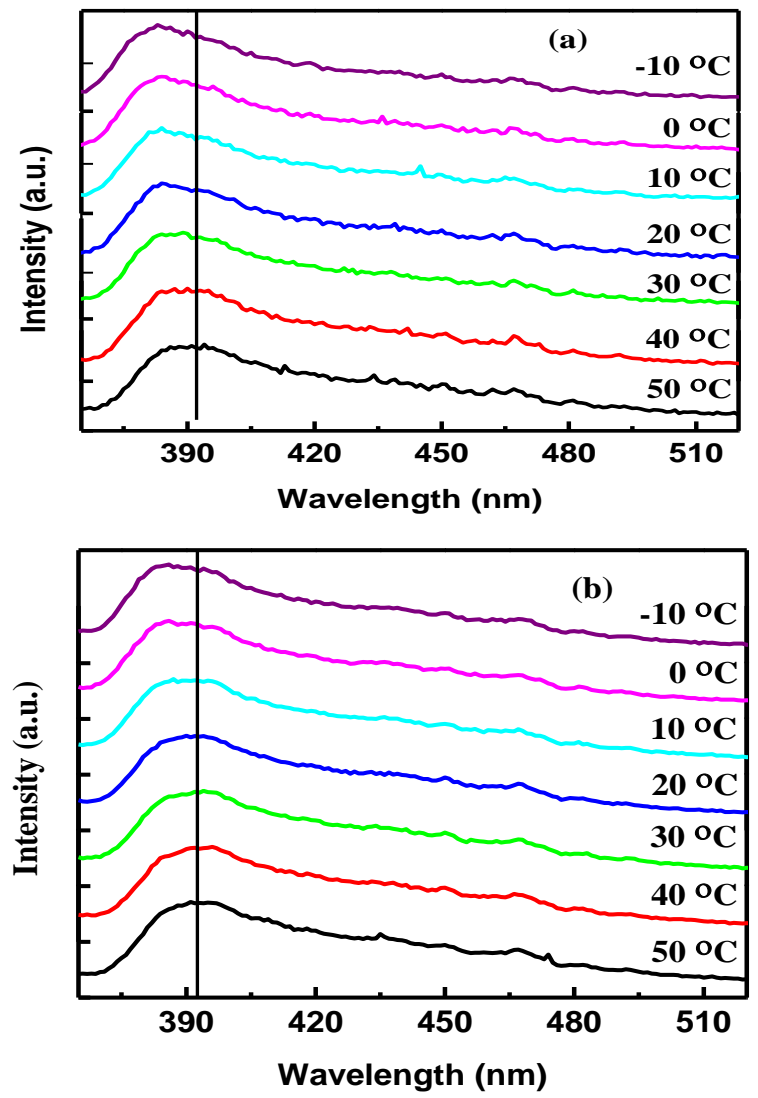

Fig. 6-Temperature dependent PL emission spectra of (a) undoped and (b) Ce doped $\mathrm{ZnO} \mathrm{NPs}$

The blue-shift of the UV emission peak with reduction of temperature is attributed to Varshni relationship [12]. The weak blue emission peaks observed at 467, 480 and $490 \mathrm{~nm}$ generally originate because of the transitions between the oxygen vacancies and interstitial oxygen and intrinsic or extrinsic defects in the crystals structure [13]. The blue emission peaks do not notice any significant change in their intensity or position due to temperature variation. As high temperature annealing was performed after synthesis of the NPs, the defects plausibly got stabilized, that is why the emission caused due to them is unchanged.

The temperature dependent PL spectra of Ce doped ZnO NPs too have the similar peaks, as shown in Fig. 2b. Here a very feeble change in the intensity of UV peak, with temperature, is noticed. The blue-shift is also visible when temperatures reaches below $0{ }^{\circ} \mathrm{C}$. Other blue emission peaks are available and remain unaffected under temperature variation. It seems that Ce doping controls the shift of the band gap in low temperature regime. Such temperature dependent PL properties and control of band gap can be effective in optoelectronic applications. Also band gap enhancement with Ce doping in $\mathrm{ZnO}$ NPs is also a significant observation.

\section{CONCLUSIONS}

Sol-gel derived undoped $\mathrm{ZnO}$ NPs show $\mathrm{Zn}-\mathrm{O}$ bond in stretching mode under tetrahedral coordination which shift to higher wavenumber due to Ce doping. The band gap gets blue-shifted in CZO because of more and more electron-electron scattering. The morphology 
changes from platelet to hexagonal rod-like structures. The temperature dependent PL of undoped $\mathrm{ZnO}$ demonstrates blue-shift in the UV emission peak along with rise in intensity, with reduction in temperature, which is supported by Varshni relation. CZO's UV emission depicts the blue-shift only in the negative temperature range. Such temperature dependent PL properties and control of band gap can be significant in optoelectronic applications.

\section{ACKNOWLEDGEMENTS}

Authors (SC, KPM) acknowledge the financial grant provided by UGC-DAE-CSR (Mumbai Centre) through a collaborative research scheme (CRS) project (vide letter no. Ref: UDCSR/MUM/AO/CRS-M-316/2020/814 dated July 13; 2020). The authors thank Central Analytical Facility (CAF), Manipal University Jaipur (MUJ), India, for UV-Vis and PL measurements. Sophisticated Analytical Instrumentation Facility (SAIF) of MUJ, India, for FESEM measurements, is duly acknowledged. Ashok Kumawat expresses gratitude towards Ramdas Pai Scholarship of MUJ, India.

\title{
REFERENCES
}

1. S. Chattopadhyay, K.P. Misra, A. Agarwala, A. Rao, P.D. Babu, Mater. Chem. Phys. 227, 236 (2019).

2. W.W. Anku, E.S. Agorku, S.O.B. Oppong, A.Y. Karikari, SN Appl. Sci. 2, 972 (2020).

3. H.P. He, H.P. Tang, Z.Z. Ye, L.P. Zhu, B.H. Zhao, L. Wang, X.9. K.P. Misra, A. Kumawat, A Shahee, S. Chattopadhyay, Mater. H. Li, Appl. Phys. Lett. 90, 023104 (2007).

4. B.G. Shohany, A.K. Zak, Ceram. Int. 46(5), 5507 (2020).

5. D.K. Sharma, M. Varshney, S. Shukla, K.K. Sharma, V. Kumar, A. Sharma, Vacuum 179, 109522 (2020).

6. J. Wang, T. Shen, Y. Feng, H. Liu, Physica B: Condens. Matter 576, 411720 (2020).

7. B. Abderrahmane, A. Djamila, N. Chaabia, R. Fodil, J. Alloy. Compd. 829, 154498 (2020).

8. A. Chelouche, T. Touam, D. Djouadi, A. Aksas, Optik 125(19), 5626 (2014) Technol. 1 (2020)

10. A. Kumawat, S. Chattopadhyay, K.P. Misra, N. Halder, S.K. Jain, B.L. Choudhary, Solid State Sci. 108, 106379 (2020).

11. S.E. Sernelius, K.F. Berggren, Z.C. Jin, I. Hamberg, C.G. Granqvist, Phys. Rev. B 37, 10244 (1988).

12. Y.P. Varshni, Physica 34, 149 (1967).

13. P. Pandey, R. Kurchania, F.Z. Haque, Optik 126(21), 3310 (2015).

\section{Збільшення ширини забороненої зони і температурно-залежна ФЛ в золь-гель синтезованих наночастинках $\mathrm{ZnO}$, легованих Се}

\author{
Ashok Kumawat, Saikat Chattopadhyay, Nilanjan Halder, Kamakhya Prakash Misra
}

Department of Physics, School of Basic Sciences, Manipal University Jaipur, 303007 Rajasthan, India

\begin{abstract}
Золь-гель синтез був використаний для одержання нелегованих і легованих 2 ат. \% Се наночастинок (НЧ) ZnO (CZO). Виразні характерні піки поглинання при 520 та $524 \mathrm{~cm}^{-1}$ спостерігаються у спектрах FTIR HЧ, які зазвичай відповідають режиму розтягування Zn-O. Це підтвердило утворення $\mathrm{ZnO}$ у зразках. Також спостерігалися інші піки при 628 та $631 \mathrm{~cm}^{-1}$, що відповідають антисиметричним коливанням Zn-O-Zn. Спектри пропускання УФ та видимого випромінювання виявили провали поглинання при 370 та 364 нм відповідно для нелегованих НЧ ZnO та CZO, а відповідні значення ширини забороненої зони становили 3,34 та $3,41 \mathrm{eB}$. Спектри випромінювання фотолюмінесценції (ФЛ) нелегованих НЧ ZnO мали один основний пік при 391 нм (УФ) разом із слабкими видимими піками при 467, 480 та 492 нм. УФ пік демонструє постійне зростання інтенсивності із зниженням температури в межах від 50 до $-10^{\circ} \mathrm{C}$. УФ пік також злегка зміщуеться у синю область із зниженням температури. Температурно-залежні спектри ФЛ НЧ CZO теж мали подібні піки, але було помічено дуже слабку зміну інтенсивності з температурою, і зсув УФ піку у синю область відбувся при негативній температурі. Залежні від температури властивості ФЛ та збільшення ширини забороненої зони НЧ CZO можуть мати потенщійне застосування в оптоелектроніці.
\end{abstract}

Ключові слова: Метод золь-гелю, $\mathrm{CeZnO,} \mathrm{Збільшення} \mathrm{ширини} \mathrm{забороненої} \mathrm{зони,} \mathrm{Залежна} \mathrm{від} \mathrm{темпе-}$ ратури фотолюмінесценція, Додатки оптоелектроніки. 